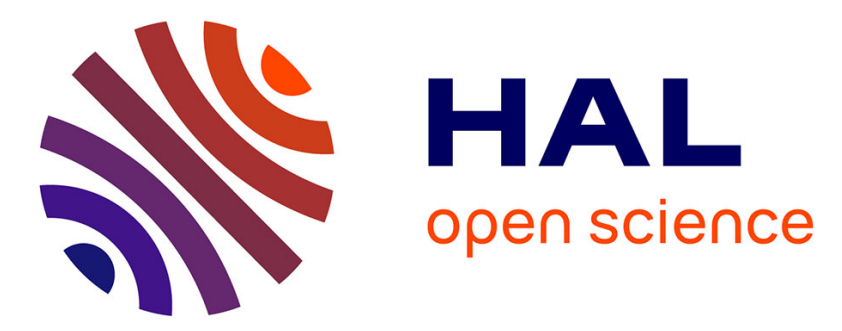

\title{
Occurrence of sombric-like subsurface A horizons in some andic soils of the Nilgiri Hills (Southern India) and their palaeoecological significance
}

Laurent Caner, François Toutain, G. Bourgeon, A.J. Herbillon

\section{- To cite this version:}

Laurent Caner, François Toutain, G. Bourgeon, A.J. Herbillon. Occurrence of sombric-like subsurface A horizons in some andic soils of the Nilgiri Hills (Southern India) and their palaeoecological significance. Geoderma, 2003, 117, pp.251-265. 10.1016/S0016-7061(03)00127-7 . hal-00258683

\section{HAL Id: hal-00258683 \\ https://hal.science/hal-00258683}

Submitted on 24 Feb 2008

HAL is a multi-disciplinary open access archive for the deposit and dissemination of scientific research documents, whether they are published or not. The documents may come from teaching and research institutions in France or abroad, or from public or private research centers.
L'archive ouverte pluridisciplinaire HAL, est destinée au dépôt et à la diffusion de documents scientifiques de niveau recherche, publiés ou non, émanant des établissements d'enseignement et de recherche français ou étrangers, des laboratoires publics ou privés. 


\section{Occurrence of sombric-like subsurface A horizons in some andic soils of the Nilgiri Hills (Southern India) and their palaeoecological significance}

Laurent CANER $^{\mathrm{a}}$, François TOUTAIN $^{\mathrm{b}}$, Gérard BOURGEON $^{\mathrm{c}}$ and Adrien-Jules HERBILLON ${ }^{\mathrm{d}}$

\section{Accepted version: Geoderma, 117, 251-267}

Laurent CANER ${ }^{\mathbf{a}}$ Université de Poitiers, UMR 6532 HYDRASA, Bâtiment des Sciences Naturelles, 40, Avenue du Recteur Pineau, 86022 Poitiers - France. E-mail: laurent.caner@univ-poitiers.fr. Phone: +33 (0)5 49453670 - Fax: +33 (0)5 49454241.

\section{François TOUTAIN ${ }^{\text {b }}$}

Laboratoire des Interactions Microorganismes - Minéraux - Matière Organique dans les SolsLIMOS, FRE 2440 CNRS, 17, rue Notre-Dame des Pauvres BP5, 54501 Vandœuvre-LèsNancy, France, Tel : 0383510860 , Fax : 0383576523

\section{Gérard BOURGEON}

CIRAD-AMIS - Agronomie MOST, TA 40 / 01, 34398 Montpellier Cedex 5, France Tel : 04676171 86, Fax : 04676156 42, Mail: bourgeon@cirad.fr

\section{Adrien-Jules HERBLLON ${ }^{d}$}

Unité des Sciences du Sol, Université Catholique de Louvain, 210, Place Croix-du-Sud, Louvain-la-Neuve, Belgium. Mail : herbillon@sols.ucl.ac.be 


\begin{abstract}
This paper deals with four pedons (three Fulvudands and one Andic Haplorthox), located at high elevations (2000-2400 m a.s.1) in the Nilgiri Hills on an old laterized surface of South India, and characterized by thick $(50-100 \mathrm{~cm})$ epipedons whose colour tends to darken with depth. In two of them, the colour contrast between the top and the bottom A horizons was so well expressed that they were morphologically very similar to the African Oxisols reported to have sombric subsurface horizons. Soil organic matter (SOM) of the different selected A horizons was characterized by its mean residence time and its $\delta^{13} \mathrm{C}$ value, whereas their humic acids were examined by techniques that made it possible to determine their chemical composition and their chromatic properties. It was found that the darker colour of the subsurface A horizons of these soils was related to three joined characteristics: a SOM $\delta^{13} \mathrm{C}$ signature indicating a C4-type vegetation (i.e. a grassland-type) origin, the presence of humic acids belonging to the A-type (i.e. melanic) category of Kumada (1987), and large mean residence time values. In contrast, the top A horizons had a more recent SOM, mainly inherited from a C3-type vegetation, and humic acids (HAs) that were less condensed than the A-type HAs. It was also found that where the presence of sombric-like subsurface A horizons was the most evident, the vegetation change recorded by the soils (i.e. the change from a grassland-type vegetation towards a C3-type vegetation) was expressed on the thickest part of their epipedon.

These observations led us to propose that the occurrence of sombric-like subsurface A horizons resulted from the following sequence of events: (i) an exceptionally thick accumulation of organic matter deriving from grassland followed by (ii) its progressive replacement by less dark organic matter deriving from a C3-type vegetation. This proposal was found to be in reasonable agreement with the history of the vegetation changes experienced by the Nilgiri Hills since the end of the Pleistocene. On the other hand, it is also very similar to one of the hypotheses proposed by Van Wambeke (1992) to explain the frequent occurrence of sombric horizons in the Oxisols and Ultisols of the high-altitude areas of Central Africa.
\end{abstract}

\title{
1. Introduction
}

Although sombric horizons are known to occur extensively in Oxisols and Ultisols of the high-altitude areas of Central Africa (as an example, see Frankart, 1983, and more recently, the soil map of Rwanda by Baert et al., 2000), the genesis of this diagnostic subsurface 
horizon remains poorly understood. Its present definition (Soil Survey Staff, 1999), which dates from the time of the introduction of this particular B horizon into the soil classification system of Congo (Sys et al., 1961), considers it as a horizon containing illuvial humus not associated with aluminium. However, the illuvial origin of its humus was frequently questioned (Frankart, 1983; Neel, 1983; AGCD, 1987; Buol and Eswaran, 1987; Mutwewingabo, 1989) during the eighties, in particular. Thus, views have also been expressed that the sombric horizons might be either buried A horizons or, in some locations at least, the present-day subsurface remnants of thick dark A horizons formed during a previous cooler climatic period (Van Wambeke, 1992)

During a study of the organic matter-rich soils capping the low activity clay regoliths of the Nilgiri Hills (South India), Caner (2000) made observations that have led him to consider Van Wambeke's suggestion reported above in greater detail. At high elevations, on an old laterized surface in India, many soils do indeed have deep A horizons whose colour generally darkens, sometimes very distinctly, with depth. However, these horizons also have exceptionally large contents of metal-humus complexes and, for this reason, the soils under consideration frequently belong to the Andisol Order (Caner et al., 2000). If we also keep in mind that colour and melanic index value in Andisols are two characteristics reflecting the type of vegetation (i.e. grass versus forest) under which the soils have evolved (Shoji, 1988), it could then be hypothesized that the darkening of colour with depth observed in Nilgiri soils might be indicative of vegetation changes.

The purpose of this paper is to present observations and analytical data to document this hypothesis. Firstly, we will show that both the organic matter and the humic acids of the Nilgiri Andisols or andic soils keep the signature of the different types of vegetation under which these soils evolved during the last millennia. Afterwards, we will demonstrate that whenever a darkening of colour is observed in their thick A horizons, this morphological modification is closely associated with a change in the origin of their organic matter. In other words, we will show that the occurrence of dark, sombric-like subsurface A horizons in the Nilgiri soils can clearly be related to the vegetation and, most likely, to the associated climatic changes that have affected this area since the end of the Pleistocene. Finally, we will examine the implications of the present study concerning the genesis of the African sombric horizons. 


\section{Materials and methods}

\subsection{Study area and its environment.}

The Nilgiri Hills (also called the Nilgiris, 2000 to $2500 \mathrm{~m}$ a.s.1.) correspond to the Precambrian charnockite massif rising at the junction of the Western and Eastern Ghâts in Southern India (Fig. 1). They result from residual erosion (Gunnell and Louchet, 2000) and have been deeply laterized during the Tertiary (Subramanian and Murthy, 1976; Subramanian and Mani, 1981). Demangeot (1975) has given a good description of the geomorphic features of this strongly rolling surface formed by low areas (or basins) of convex landforms separated by hill ranges. The thick regoliths inherited from this previous weathering cycle constitute, in most places, the present day parent materials of the soils.

In the Nilgiris, the climatic conditions are characterized by a mean annual temperature of about $15^{\circ} \mathrm{C}$ and by rainfall regimes showing very drastic changes over short distances along a West-East gradient. In consequence, precipitations range from $5000-2500 \mathrm{~mm}^{-1}{ }^{-1}$ in the western part subjected to the south-west monsoon, from $2000-1500 \mathrm{~mm}$ in the eastern part receiving convective rains, and from $1200-900 \mathrm{~mm}$ in the central part exposed to a mixed regime. The native vegetation, largely disturbed by human activities, corresponds to a mosaic of stunted, high-elevation, evergreen forest (locally called 'shola') dominated by Lauracea, Myrtacea and Ericacea species, and grasslands of different floristic compositions including a majority of C4 species (Cymbopogon, Arundinela, Chrysopogon, Themeda, Blasco, 1971; Sutra, 1997). The origin and the present day dynamics of this grassland-forest mosaic are subject matters that have been much debated (Blasco, 1971; Gupta and Prasad, 1985; Sukumar et al., 1993; Rajagopalan et al., 1997). However, it is generally accepted at this time that they are the result of the climatic variations and the associated vegetation changes that have affected this area over the last 20,000 years (Sukumar et al., 1993).

Under residual forests or tree plantations that preserved them from erosion or noticeable human disturbances, the Nilgiri soils are characterized by thick A horizons (several tens of centimetres to one metre), darkened by organic matter overlaying reddish earthy materials. As already noted, these soils that were mapped as Oxic Humitropets or Typic Haplohumults by Seghal et al. (1996) can now often be classified as Andisols. Indeed, though devoid of allophane, these soils are always rich in metal-humus complexes and owe their andic properties to the weathering reactions that have taken place between their humic substances and the oxides inherited from their pre-weathered 'lateritic' parent materials (Caner et al., 2000). 


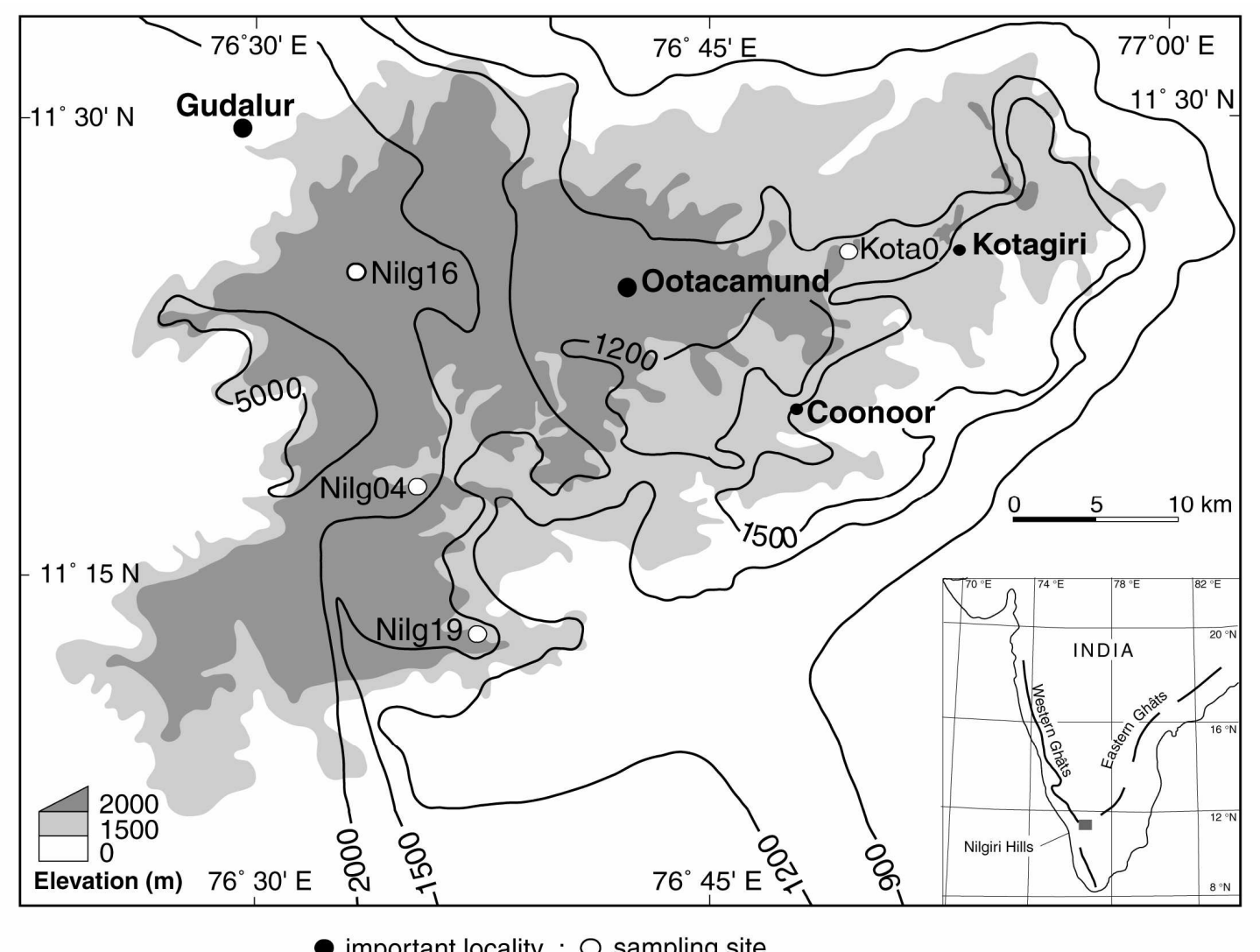

Figure 1. Environmental setting of the Nilgiri Hills and location of the four selected sampling sites

\subsection{Sampling}

Four pedons, differing mainly in the thickness and colour of their epipedons, were selected for the present study (Fig. 2) among the Nilgiris' soil profiles examined by Caner (2000). In the first two (Nilg 4 and Nilg 16, Fig. 2, top), the upper part of the epipedon was almost homogeneously dark reddish brown but a lightening of colour towards the soil surface was nevertheless noticeable. In the other two (Nilg 19 and Kota 0, Fig. 2, bottom) which also had the deepest epipedon, the change of colour between surface and subsurface (darkening with depth) was much more apparent. In addition, by observing road cuts which follow convex contours at the sites where these last two pedons were observed, the colour differences noted above were traced laterally over distances of several hundred metres, suggesting that their dark subsurface horizons were not buried A horizons.

The four pedons were located at $2100 \mathrm{~m}$ a.s.1., in different locations of the massif (Fig. 1): the Nilg 4 pedon is under forest ('shola') whereas the other three pedons are under tree plantations. Pedons were described using standard rules and symbols (Soil Survey Division Staff, 1993) and two different series of sampling were performed. 
- First, each genetic horizon was identified, labelled and described. These horizons, or different sub-horizons (labelled using a second Arabic numeral), were then sampled, sieved at $2 \mathrm{~mm}$ and the fine earth used for the routine characterization of the main properties (Tables 1 and 2).

- In a second step, samples were collected from selected layers in the thick A horizons, then wet-sieved (Gavinelli et al., 1995) to remove plant residue (mainly rootlets) and the fractions of less than $50 \mu \mathrm{m}$ were used for detailed studies of soil organic matter (SOM) (Tables 3 and 4).

\subsection{Laboratory methods}

Three sets of analyses were performed for this study: routine analyses for the global characterization of soils leading to their classification, isotope studies and organic matter analyses to document the hypothesis that vegetation changes may have played a role in the development of sombric-like horizons.

\subsubsection{Routine analyses}

The methods used to characterize the soils and to identify their andic properties were presented in Caner et al. (2000). Briefly, they consisted of the determinations making it possible to classify the pedons according to the Soil Taxonomy (Soil Survey Staff, 1999). Particle size distribution analysis was done after pre-treatment with $30 \% \mathrm{H}_{2} \mathrm{O}_{2}$ to destroy organic matter, and with acid ammonium oxalate $(\mathrm{pH} 3.0)$ to remove amorphous cements. Melanic index (MI; Honna et al., 1988) was calculated as the ratio of the absorbance at $450 \mathrm{~nm}$ to that at $520 \mathrm{~nm}$ of a soil $(0.5 \mathrm{~g}$ of fine earth) extract in $0.5 \% \mathrm{NaOH}$. Estimates of Al-humus contents were computed from the mean values of the figures obtained using the two alternative formulas proposed by Poulenard and Herbillon (2000).

\subsubsection{Carbon isotope studies}

Stable carbon isotope ratios $\left(\delta^{13} \mathrm{C}\right)$ are widely used, coupled with ${ }^{14} \mathrm{C}$ dating, to document vegetation dynamics in natural ecosystems where $C_{3}$ and $C_{4}$ plant communities coexist (or may have coexisted) (Boutton, 1996). In the present paper, $\delta^{13} \mathrm{C}$ ratios were determined after combustion of $<50 \mu \mathrm{m}$ soil fractions in sealed quartz tubes with $\mathrm{CuO}$ and $\mathrm{Cu}_{2} \mathrm{O}$ at $950^{\circ} \mathrm{C}$ for $4 \mathrm{~h}$. 

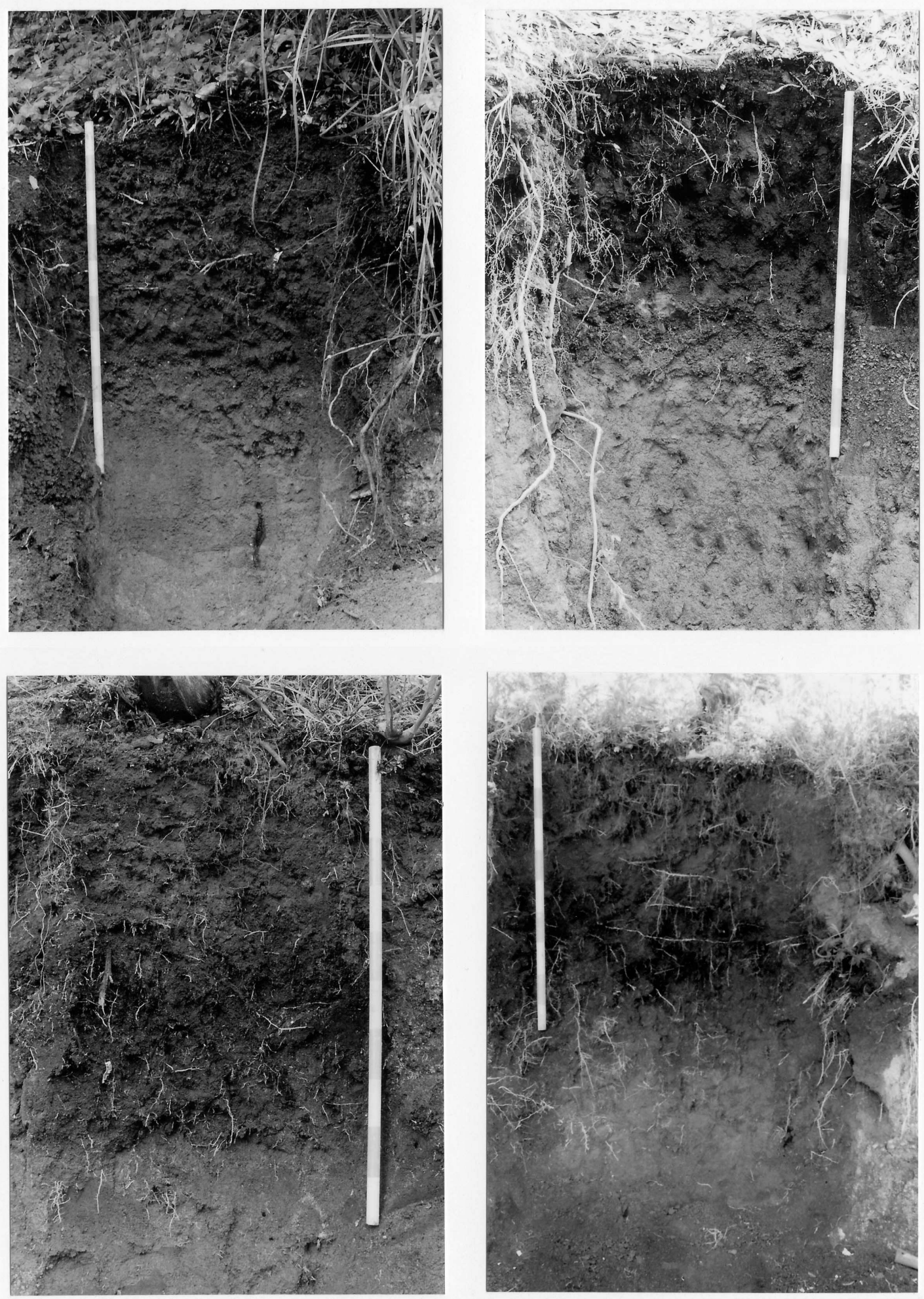

Figure 2: Photographs illustrating the four pedons of this study. These photographs show the superposition of thick, organic matter-rich A horizons above reddish 'lateritic' materials. A gravelly stone line always demarcates the transition. Top: typical Nilgiris soils displaying rather uniform dark reddish brown (5 YR 2.5/2) epipedons, (left: pedon Nilg 4; right: pedon Nilg 16). Bottom: soils which present the thickest epipedons and subsurface A horizons (5 YR 2.5/2), darker than the surface ones (10YR 3/4 or 5YR 3/3), (left: pedon Nilg 19; right: pedon Kota 0 ). In the present paper, the subsurface dark horizons of Nilg 19 and Kota 0 were referred as sombric-like subsurface A horizons. 
The $\mathrm{CO}_{2}$ was isolated and purified by cryogenic distillation and its ${ }^{13} \mathrm{C}$ isotope composition determined (Micromass VG 602D). Isotope ratios were expressed as $\delta^{13} \mathrm{C}$ relative to the NBS (VPDB) standard according to the formula:

$\delta^{13} \mathrm{C}=\left[\left(\mathrm{R}_{\text {sample }} / \mathrm{R}_{\mathrm{VPDB}}\right)-1\right] \times 1000$, where $\mathrm{R}$ is the ${ }^{13} \mathrm{C} /{ }^{12} \mathrm{C}$ ratio.

${ }^{14} \mathrm{C}$ dating was performed on the $<50-\mu \mathrm{m}$ soil fractions by the liquid scintillation method (Balesdent and Guillet, 1982). Samples with weights equivalent to $5 \mathrm{~g}$ of organic carbon were burnt at $900^{\circ} \mathrm{C}$ under $\mathrm{O}_{2}$ flow. The resulting $\mathrm{CO}_{2}$ was purified by cryogenic distillation and converted into benzene of which ${ }^{14} \mathrm{C}$ activity was determined relative to the NBS standard. ${ }^{14} \mathrm{C}$ activities were corrected for isotope fractionation and expressed as $\Delta^{14} \mathrm{C}$, according to the following the formula:

$\Delta^{14} \mathrm{C}=\delta^{14} \mathrm{C}-\left[\left(2 \delta^{13} \mathrm{C}+50\right) \times\left(1+\left(\delta^{14} \mathrm{C} / 1000\right)\right)\right]$

with $\delta^{14} \mathrm{C}$ being the measured activity of the sample.

For surface samples which presented $\Delta^{14} \mathrm{C}$ positive values, the mean residence time of SOM (MRT) was computed using a model which took the incorporation of ${ }^{14} \mathrm{C}$ derived from the atmospheric nuclear tests in the SOM (Balesdent and Guillet, 1982; Balesdent, 1987) into account. For subsurface horizons, MRT was computed from the $\Delta{ }^{14} \mathrm{C}$ activity using a ${ }^{14} \mathrm{C}$ half-life of 5,568 years.

\subsubsection{Organic matter analyses}

Humic compounds were obtained by repeated extractions on the $<50 \mu \mathrm{m}$ soil fraction with a mixture of $0.1 \mathrm{~N} \mathrm{NaOH}$ and $1 \% \mathrm{Na}_{4} \mathrm{P}_{2} \mathrm{O}_{7}$. Humic acids (HAs) were precipitated at $\mathrm{pH} 2$, kept for 16 hours at $4{ }^{\circ} \mathrm{C}$ and centrifuged. HAs were purified by dialysis (Spectra-Por 6, molecular-weight cut-off $6000 \mathrm{da}$ ), decationised through cation-exchange resin (Amberlite IR 120) and freeze-dried before analysis. Only total carbon was measured on the fulvic acids (FAs).

Elemental analysis of $\mathrm{C}, \mathrm{H}, \mathrm{N}$ and $\mathrm{O}$ of $\mathrm{HAs}$ was performed on a $\mathrm{CHN}+\mathrm{O}$ autoanalyser (Carlo Erba 1108). Ash content was determined by loss on ignition at $700^{\circ} \mathrm{C}$.

The absorbance of the HAs in UV-visible light, especially their brown colour, is attributed to the conjugated double bonds distributed in the structure and is correlated with the humification degree (Stevenson, 1982). In consequence, the colour intensity of suspensions of humic substances was measured in order to get an estimation of the degree of humification and to compare profiles or horizons within a profile. 
We employed the criteria defined by Kumada (1987) and further modified by Arai et al. (1996). The absorbance of HAs at 400 and $600 \mathrm{~nm}\left(A_{400}\right.$ and $\left.A_{600}\right)$ was recorded from $0.1 \mathrm{~N}$ $\mathrm{NaOH}$ solutions, containing 1\% of HA, on a Beckman DU 70 spectrophotometer. The colour coefficient $\left(\Delta \log K=\log A_{400}-\log A_{600}\right)$ and the colour intensity $\left(A_{600} / C\right.$, where $C$ is the carbon concentration of the suspension) of the HAs were calculated. $A_{600} / C$ values were then plotted against $\Delta \log K$ values to determine the type of HAs (i.e. A-type, B-type, P-type or Rp-type) present (Kumada, 1987; Arai et al, 1996). The degree of humification of the HAs increases as $\Delta \log K$ decreases and $A_{600} / C$ increases; $\Delta \log K<0.65$ and $A_{600} / C>5$ are considered as characteristic of A-type (i.e. melanic) HAs.

Fourier-transformed infrared (FT-IR) spectra were obtained by absorbance from $\mathrm{KBr}$ pellets (1 mg HA pressed under vacuum in $200 \mathrm{mg} \mathrm{KBr}$ ) on a Bruker Vector 22 FTIR spectrophotometer.

Solid-state ${ }^{13} \mathrm{C}-\mathrm{NMR}$ spectra of HAs with cross polarization and magic angle spinning (CPMAS NMR) were obtained on a Bruker DSX 300 operating at $75.47 \mathrm{MHz}$. The rotor spin rate was set at $4 \mathrm{kHz}$. Spectra were acquired with a $1 \mathrm{~ms}$ contact time, $5 \mathrm{~s}$ recycle time and a $13 \mathrm{~ms}$ acquisition time. Chemical shifts are reported relative to tetramethylsilane at $0 \mathrm{ppm}$. Spectra were divided into chemical regions according to Preston (1996), Kögel-Knabner (1997) and Golchin et al. (1997): 0-46 ppm, aliphatic carbon; 46-110 ppm, O-alkyl; 110160 ppm, aromatic carbon; 160-210 ppm, carbonyl.

\section{Results}

\subsection{Soil morphology}

The morphological characteristics of the four selected pedons are summarized in Table 1 and illustrated in Figure 2. All soils exhibit two groups of horizons (Fig. 2) separated by a gravelly stone line $(\mathrm{Bw})$, rich in ironstone nodules demarcating a lithological discontinuity.

- In depth, below the stone line, the $2 \mathrm{Bo}$ horizons have bright reddish colours. They are almost structureless but contain microaggregates, reminiscent of the structural features of an Oxic horizon. These $2 \mathrm{Bo}$ horizons are also very rich in $\mathrm{Al}$ and $\mathrm{Fe}$ oxides and very poor in weatherable minerals (for Nilg 4 and Nilg 16, see data in Caner et al., 2000).

- Similarly, the epipedons, above the stone line, have a weakly developed structure. In all soils, the subsurface A horizons are somewhat darker than the surface ones, these colour differences and, thus, the contrast between the two groups of A horizons being much more 
Table 1: Environment, morphological characteristics and general properties of the selected pedons

\begin{tabular}{|c|c|c|c|c|c|c|c|}
\hline $\begin{array}{l}\text { Pedon } \\
\text { (location, Rainfall) }\end{array}$ & Horizon & Depth (cm) & $\begin{array}{l}\text { Colour } \\
\text { (moist) }\end{array}$ & $\begin{array}{l}\text { Textural } \\
\text { classes }^{a}\end{array}$ & Structure & $\frac{\text { Clay }}{\left(\mathrm{g} \mathrm{kg}^{-1}\right)^{\mathrm{b}}}$ & $\begin{array}{c}\mathrm{pH} \\
\text { water }\end{array}$ \\
\hline \multicolumn{8}{|c|}{ Nilg $4\left(11^{\circ} 17^{\prime} 56^{\prime \prime}, N, 76^{\circ} 35^{\prime} 57^{\prime \prime} \mathrm{E}\right.$; $\left.2200 \mathrm{~mm}_{\text {year }}{ }^{-1}\right)$} \\
\hline & $\mathrm{A}_{1}$ & $0-30$ & $5 Y R 3 / 2$ & $\mathrm{cl}$ & very fine granular & 550 & 5.09 \\
\hline & $\mathrm{A}_{2}$ & $30-55$ & $5 Y R 2.5 / 2$ & $\mathrm{cl}$ & massive & 510 & 4.93 \\
\hline & $\mathrm{Bw}$ & $55-65$ & $5 Y R 3 / 3$ & $\operatorname{sc} g$ & massive & 400 & 5.01 \\
\hline & $2 \mathrm{Bo}_{1}$ & $65-110$ & $2.5 \mathrm{YR} 3 / 6$ & $\mathrm{cg}$ & massive & 490 & 5.03 \\
\hline & $2 \mathrm{Bo}_{2}$ & $110-150$ & $2.5 \mathrm{YR} 3 / 6$ & c & massive & 460 & 5.04 \\
\hline \multicolumn{8}{|c|}{ Nilg $16\left(11^{\circ} 24^{\prime} 57^{\prime \prime} N, 76^{\circ} 34^{\prime} 50^{\prime \prime}\right.$ E; 2500 mm year $\left.^{-1}\right)$} \\
\hline & $\mathrm{A}_{1}$ & $0-20$ & $7.5 \mathrm{YR} 3 / 2$ & $\mathrm{cl}$ & granular & 420 & 4.54 \\
\hline & $\mathrm{A}_{2}$ & $20-45$ & 5YR $2.5 / 2$ & $\mathrm{cl}$ & massive & 400 & 4.85 \\
\hline & $\mathrm{A}_{3}$ & $45-60$ & 5YR $2.5 / 2$ & $\mathrm{cl}$ & massive & 610 & 5.37 \\
\hline & $\mathrm{A}_{4}$ & $60-70$ & 5YR 3/3 & sc g & massive & 480 & 5.56 \\
\hline & $\mathrm{Bw}$ & $70-85$ & $5 Y R 3 / 3$ & $\mathrm{cg}$ & massive & 530 & 5.62 \\
\hline & $2 \mathrm{Bo}_{1}$ & $85-100$ & $2.5 \mathrm{YR} 3 / 6$ & c & massive & 670 & 5.75 \\
\hline & $2 \mathrm{Bo}_{2}$ & 160 & $10 \mathrm{R} 4 / 6$ & c & massive & 760 & 5.89 \\
\hline \multicolumn{8}{|c|}{ Nilg $19\left(11^{\circ} 13^{\prime} 02{ }^{\prime \prime} N, 76^{\circ} 37^{\prime} 19^{\prime \prime}\right.$ E; 1700 mm year $\left.^{-1}\right)$} \\
\hline & $\mathrm{A}_{1}$ & $0-15$ & $10 \mathrm{YR} 3 / 4$ & $\mathrm{cl}$ & very fine granular & 380 & 4.63 \\
\hline & $\mathrm{A}_{2}$ & $15-45$ & $10 \mathrm{YR} 3 / 4$ & $\mathrm{cl}$ & massive & 370 & 5.43 \\
\hline & $\mathrm{A}_{3}$ & $45-90$ & $5 Y R 2.5 / 2$ & $\mathrm{cl}$ & massive & 470 & 4.45 \\
\hline & $\mathrm{A}_{4}$ & $90-120$ & $5 Y R 2.5 / 2$ & c & massive & 490 & 3.98 \\
\hline & $\mathrm{Bw}$ & $120-135$ & $5 \mathrm{YR} 4 / 4$ & sc $g$ & massive & 540 & 3.91 \\
\hline & $2 \mathrm{Bo}_{1}$ & $135+$ & $2.5 \mathrm{YR} 3 / 6$ & sc & massive & 330 & 4.35 \\
\hline \multicolumn{8}{|c|}{ Kota $0\left(11^{\circ} 24^{\prime} 55^{\prime \prime} N, 76^{\circ} 49^{\prime} 24^{\prime \prime} E ; 1300\right.$ mm year $\left.^{-1}\right)$} \\
\hline & $\mathrm{A}_{1}$ & $0-20$ & $5 Y R 3 / 3$ & $\mathrm{cl}$ & very fine granular & 480 & 4.09 \\
\hline & $\mathrm{A}_{2}$ & $20-50$ & $5 Y R 3 / 3$ & $\mathrm{cl}$ & massive & 650 & 4.62 \\
\hline & $\mathrm{A}_{3}$ & $50-90$ & $5 Y R 2.5 / 2$ & $\mathrm{cl}$ & massive & 620 & 4.61 \\
\hline & $\mathrm{A}_{4}$ & $90-120$ & $5 Y R 2.5 / 2$ & sc & massive & 520 & 4.77 \\
\hline & $\mathrm{Bw}$ & $120-135$ & $2.5 \mathrm{YR} 3 / 4$ & sc g & massive & 490 & 4.79 \\
\hline & $2 \mathrm{Bo}_{1}$ & $150-160$ & 5YR 4/6 & $\mathrm{sc}$ & massive & 620 & 4.73 \\
\hline
\end{tabular}

a Textural classes: sc, sandy clay; c, clay; cl, clay loam; g, gravels.

${ }^{\mathrm{b}}$ Clay : content in clay after destruction of organic matter and an oxalate pre-treatment.

evident where the epipedons are the thickest, i.e. in Kota 0 and Nilg 19 pedons. In the last case especially, the subsurface A horizons are characterized by a darkening corresponding to two units of the Munsell values and a distinctly more reddish hue.

In consequence, the Nilg 19 and Kota 0 pedons exhibit clear morphological similarities to those African Oxisols whose deep umbric epipedon was reported to merge with their sombric horizon (Eswaran and Tavernier, 1980). They, however, differ from some of the low-activity clay soils with a sombric horizon described by Sys (1972) by the fact that their dark subsurface horizons do not occur below a brighter B horizon. 


\subsection{Chemical and Physical properties and soil classification}

Selected results illustrating chemical and physical properties of the soils are listed in Table 2 . The most conspicuous of these results deal with the large soil organic C contents (21 to 174 $\mathrm{g} \mathrm{C} \mathrm{kg}^{-1}$, Table 2). Indeed, the figures lead us to estimate organic carbon stocks (up to 1-m depth) as large as 30 to $50 \mathrm{~kg} \mathrm{~m}^{-2}$.

With the exception of the Kota 0 pedon where a small $\mathrm{C}$ increase was noted in the $\mathrm{A}_{3}$ horizon, C contents regularly decreased with depth. Similarly, the optical density of oxalate extract (ODOE, Table 2) values followed the same depth trend. These results may be taken as an indication that, even in the Kota 0 pedon, the darker subsurface horizons could not be considered as B horizons containing illuvial humus. Accordingly, they were labelled as A horizons in Table 1. As a matter of fact, the comparison between the Munsell colours given in Table 1 and the $\mathrm{C}$ contents (Table 2) indicated that, in most cases, the colour darkening was associated with decreasing $\mathrm{C}$ contents. Thus, the chromatic properties of organic substances rather than their contents should be at the origin of the darkening with depth observed in the sombric-like horizons of the pedons Nilg 19 and Kota 0.

Table 2 also shows that the Nilg 4, Nilg 16, and Nilg 19 pedons had the combination of properties $\left(\mathrm{Al}_{\mathrm{O}}+1 / 2 \mathrm{Fe}_{\mathrm{o}} \geq 20 \mathrm{~g} \mathrm{~kg}^{-1}\right.$, phosphate retention $\geq 85 \%$ and bulk density $\leq 0.90 \mathrm{~g}$ $\mathrm{cm}^{-3}$ ) known as the andic soil properties and were therefore Andisols rich in Al-humus complexes (CoAl, Table 2). However, despite their large organic $\mathrm{C}$ contents, these three pedons lacked the Munsell colours (Table 1) and, sometimes, the melanic index values (Table 2) as well, required for identifying a melanic epipedon. Consequently, they had to be classified as Fulvudands. At the Subgroup level (see the pertinent data in Caner et al., 2000), they further keyed out as either Acrudoxic Fulvudands (Nilg 4) or Pachic Fulvudands (Nilg 16 and Nilg 19). In contrast, the $\mathrm{Al}_{\mathrm{o}}+1 / 2 \mathrm{Fe}_{\mathrm{o}}$ values of the top horizons of the Kota 0 pedon were less than $20 \mathrm{~g} \mathrm{~kg}^{-1}$ and this soil could not be classified as an Andisol. This pedon had an Oxic horizon below its stone line (results not shown), i.e. at an unusually great depth (135 cm and more) and, on this basis, it was tentatively classified here as a member of the Andic Hapludox Subgroup. 
Table 2: Data on selective dissolutions and andic soil properties

\begin{tabular}{|c|c|c|c|c|c|c|c|c|c|}
\hline $\begin{array}{l}\text { Pedon } \\
\text {. }\end{array}$ & $\begin{array}{c}\text { Horizon / } \\
\text { layer }\end{array}$ & $\begin{array}{l}\text { Depth } \\
\mathrm{cm}\end{array}$ & $\begin{array}{l}\text { C Total } \\
\left(\mathrm{g} \mathrm{kg}^{-1}\right)\end{array}$ & $\begin{array}{c}\mathrm{Al}_{\mathrm{o}}+1 / 2 \mathrm{Fe}_{\mathrm{o}} \\
\left(\mathrm{g} \mathrm{kg}^{-1}\right)\end{array}$ & $\begin{array}{l}\mathrm{CoAl}^{\mathrm{a}} \\
\left(\mathrm{g} \mathrm{kg}^{-1}\right)\end{array}$ & $\mathrm{ODOE}^{6}$ & $\begin{array}{c}\text { P retention } \\
(\%)\end{array}$ & $\begin{array}{c}\text { Bulk density } \\
\left(\mathrm{kg} \mathrm{dm}^{-3}\right)\end{array}$ & $\mathrm{MI}^{\mathrm{c}}$ \\
\hline \multicolumn{10}{|l|}{ Nilg 4} \\
\hline & $\mathrm{A}_{1}$ & $0-30$ & 79.3 & 26.0 & 180 & 1.08 & 97 & 0.74 & 1.92 \\
\hline & $\mathrm{A}_{2}$ & $30-55$ & 40.0 & 25.2 & 150 & 0.99 & 98 & 0.89 & 1.53 \\
\hline & $\mathrm{Bw}$ & $55-65$ & 20.6 & 17.1 & 70 & 0.90 & 85 & 0.95 & 1.56 \\
\hline & $2 \mathrm{Bo}_{1}$ & $65-110$ & 10.1 & 10.6 & nd & 0.48 & 83 & 0.98 & nd \\
\hline & $2 \mathrm{Bo}_{2}$ & $110-150$ & 6.5 & 9.3 & nd & nd & 83 & 1.10 & nd \\
\hline \multicolumn{10}{|c|}{ Nilg 16} \\
\hline & $A_{1}$ & $0-20$ & 139.0 & 29.5 & 170 & 1.10 & 98 & 0.47 & 1.66 \\
\hline & $\mathrm{A}_{2}$ & $20-45$ & 81.8 & 35.6 & 220 & 1.05 & 99 & 0.49 & 1.59 \\
\hline & $\mathrm{A}_{3}$ & $45-60$ & 49.2 & 30.8 & 210 & 0.91 & 99 & 0.65 & 1.60 \\
\hline & $\mathrm{A}_{4}$ & $60-70$ & 31.4 & 25.7 & 160 & 0.81 & 99 & 0.72 & 1.73 \\
\hline & $\mathrm{Bw}$ & $70-85$ & 26.6 & 23.2 & 160 & 0.81 & 98 & 0.80 & 1.68 \\
\hline & $2 \mathrm{Bo}_{1}$ & $85-100$ & 6.4 & 7.9 & nd & nd & 85 & 0.95 & nd \\
\hline & $2 \mathrm{Bo}_{2}$ & 160 & 3.4 & 9.3 & nd & nd & 96 & 1.09 & nd \\
\hline \multicolumn{10}{|l|}{ Nilg 19} \\
\hline & $\mathrm{A}_{1}$ & $0-15$ & 112.2 & 24.9 & 140 & 0.86 & 90 & 0.65 & 2.10 \\
\hline & $\mathrm{A}_{2}$ & $15-45$ & 75.0 & 29.6 & 160 & 0.90 & 95 & 0.69 & 1.90 \\
\hline & $\mathrm{A}_{3}$ & $45-90$ & 28.9 & 22.7 & 130 & 0.75 & 94 & 0.75 & 1.72 \\
\hline & $\mathrm{A}_{4}$ & $95-120$ & 14.4 & 12.7 & 50 & 0.74 & 77 & 0.92 & 1.90 \\
\hline & $\mathrm{Bw}$ & $120-135$ & 6.5 & 4.7 & nd & 0.37 & 63 & 1.23 & nd \\
\hline & $2 \mathrm{Bo}_{1}$ & 160 & 6.0 & 3.3 & nd & 0.13 & nd & nd & nd \\
\hline \multicolumn{10}{|l|}{ Kota 0} \\
\hline & $\mathrm{A}_{1}$ & $0-20$ & 92.2 & 18.6 & 100 & 0.91 & 89 & 0.70 & 2.10 \\
\hline & $\mathrm{A}_{2}$ & $20-50$ & 37.0 & 15,6 & 100 & 0.71 & nd & 0.77 & 1.73 \\
\hline & $\mathrm{A}_{3}$ & $50-90$ & 42.4 & 19.0 & 110 & 0.70 & 96 & 0.80 & 1.60 \\
\hline & $\mathrm{A}_{4}$ & $90-120$ & 36.0 & 26.2 & 160 & 0.84 & 99 & 0.87 & 1.70 \\
\hline & $\mathrm{Bw}$ & $120-135$ & 22.1 & 17.1 & 100 & 0.61 & 94 & 1.05 & 1.85 \\
\hline & $2 \mathrm{Bo}_{1}$ & $150-160$ & 8.9 & 8.9 & nd & nd & 75 & 1.20 & nd \\
\hline
\end{tabular}

${ }^{a} \mathrm{CoAl}$ : Al-humus contents estimated according to Poulenard and Herbillon (2000).

${ }^{\mathrm{b}}$ ODOE: Optical density of the oxalate extract measured by the method of Daly (1982).

${ }^{\circ}$ MI: Melanic index following Honna et al. (1988).

\subsection{Soil carbon isotope studies}

For the bottom $\left(\mathrm{A}_{3}, \mathrm{~A}_{4}, \mathrm{Bw}\right)$ horizons, the $\mathrm{SOM} \delta^{13} \mathrm{C}$ values ranged from $-11.8 \%$ to $-15.9 \%$, indicative of C4-type plant origin. In contrast, the $\mathrm{SOM} \delta^{13} \mathrm{C}$ values ranged from $-23.1 \%$ to $24.2 \%$ in their $\mathrm{A}_{1}$ top soil counterparts, which clearly indicates a C3-type vegetation origin, except for the Nilg 16 topsoil $\mathrm{OM}$ where the $\delta^{13} \mathrm{C}$ value $(-17.5 \%)$ is indicative of a mixed origin (C3 and C4-type vegetation). On the other hand, some intermediate horizons of the 
Table 3: SOM general characterisation, isotope composition and dating

\begin{tabular}{llcccc}
\hline Pedons & $\begin{array}{l}\text { Horizons / } \\
\text { layers }\end{array}$ & $\begin{array}{c}\text { Depth } \\
(\mathrm{cm})\end{array}$ & $\begin{array}{c}\delta^{13} \mathrm{C} \\
(\%)\end{array}$ & $\begin{array}{c}\Delta^{14} \mathrm{C}^{\mathrm{a}} \\
(\%)\end{array}$ & $\begin{array}{c}\text { MRT } \\
(\text { years B.P.) }\end{array}$ \\
\hline Nilg 4 & $\mathrm{A}_{11}$ & $0-10$ & -24.2 & 56 & $153 \pm 20$ \\
& $\mathrm{~A}_{12}$ & $15-30$ & -19.8 & -132 & $1140 \pm 42$ \\
& $\mathrm{~A}_{22}$ & $40-55$ & -14.4 & -400 & $4100 \pm 52$ \\
& $\mathrm{BW}$ & $55-65$ & -12.5 & nd & nd \\
Nilg 16 & $\mathrm{A}_{11}$ & $0-10$ & -17.5 & 87 & $108 \pm 9$ \\
& $\mathrm{~A}_{21}$ & $20-35$ & -12.5 & -98 & $826 \pm 39$ \\
& $\mathrm{~A}_{31}$ & $45-50$ & -11.1 & -295 & $2814 \pm 42$ \\
& $\mathrm{~A}_{4}$ & $60-70$ & -12.4 & -914 & $19715 \pm 160$ \\
& $\mathrm{Bw}$ & $70-85$ & -11.8 & -963 & $26213 \pm 299$ \\
Nilg 19 & $\mathrm{A}_{11}$ & $0-10$ & -23.1 & 108 & $85 \pm 20$ \\
& $\mathrm{~A}_{21}$ & $15-25$ & -22.3 & -39 & $277 \pm 34$ \\
& $\mathrm{~A}_{22}$ & $25-40$ & -22.4 & -239 & $2192 \pm 50$ \\
& $\mathrm{~A}_{32}$ & $60-70$ & -15.2 & -808 & $13245 \pm 81$ \\
& $\mathrm{~A}_{33}$ & $70-80$ & -15.9 & nd & nd \\
& $\mathrm{A}_{42}$ & $100-120$ & -14.9 & nd & nd \\
Kota 0 & $\mathrm{A}_{1}$ & $0-20$ & -23.2 & 141 & $62 \pm 4$ \\
& $\mathrm{~A}_{22}$ & $30-40$ & -15.8 & -396 & $4054 \pm 51$ \\
& $\mathrm{~A}_{31}$ & $50-65$ & -14.8 & -450 & $4811 \pm 59$ \\
& $\mathrm{~A}_{33}$ & $80-90$ & -12.9 & -921 & $20411 \pm 154$ \\
& $\mathrm{~A}_{42}$ & $100-120$ & -12.9 & -937 & $21171 \pm 206$ \\
\hline${ }^{2}$ Corrected ${ }^{14} \mathrm{C}$ activities (see text). & &
\end{tabular}

other three pedons were similarly characterized by $\delta^{13} \mathrm{C}$ values ranging between $-14.4 \%$ and $19.8 \%$, which also indicates that their organic materials were of mixed C3 and C4-type vegetation origin. The SOM $\delta^{13} \mathrm{C}$ data therefore showed a general trend for the $\mathrm{C}_{3}$-derived SOM to increase towards the surface (Table 3 ).

The results of the ${ }^{14} \mathrm{C}$ dating (Table 3) showed a rapid increase of the mean residence time (MRT) of SOM with increasing depth and very old SOM in the deepest organic horizons (60$120 \mathrm{~cm}$; from 13,245 yr BP for pedon Kota 0 to 26,213 yr Bp for pedon Nilg 16).

Both the $\delta^{13} \mathrm{C}$ values and the ${ }^{14} \mathrm{C}$ dating illustrate the tendency for a $\mathrm{C} 4$-type vegetation to have been replaced by a C3-type vegetation, and the depth trends observed are therefore in agreement with what has been reported in several tropical areas where a savanna vegetation give way to forests (e.g. in Brazil, Desjardins et al., 1996; in Colombia, Guillet et al., 1988; in India, Mariotti and Peterschmitt, 1994). 


\subsection{Humic acid characteristics}

\subsubsection{Organic elemental analysis and infrared spectroscopy}

The organic carbon content of the humified fractions $(<50 \mu \mathrm{m})$ ranged from $59 \%$ to $83 \%$ of total soil organic carbon (SOC) in the fine earth (0-2 mm) (results not shown). Organic matter occurring in the coarse fractions $(>50 \mu \mathrm{m})$ was mainly made of rootlets. Extractable organic carbon was $35 \%$ to $38 \%$ of SOC, HA/FA ratios were about 0.8 and HAs therefore represented between $28 \%$ and $30 \%$ of the OM occurring in the humified fraction (results not shown). The $\mathrm{C}$ contents of the HAs extracted from these soils varied from 52.5 to $59.0 \%$, H contents from 2.1 to $4.9 \%, \mathrm{~N}$ from 1.5 to $5.1 \%$ and $\mathrm{O}$ contents from 34.7 to $40.0 \%$ (Table 4 ), typical of soil (Steelink, 1985) and Andisol (Yonebayashi, and Hattori, 1988) HAs. The aliphatic structure of the HAs from the $A_{1}$ horizons was revealed by their IR spectra showing an intense absorption of the double-band at $2920 \mathrm{~cm}^{-1}$ (C-H stretching) (Fig. 3) and by their large H/C atomic ratios (>1) (Table 4) (Andreux, 1978; Steelink, 1985). In contrast, the IR spectra of the HAs from the $\mathrm{A}_{3}$ horizons were characterized by the lower intensity of aliphatic groups and of absorption bands of carboxyl and carbonyl groups, whereas the aromatic bands at $1720 \mathrm{~cm}^{-1}(\mathrm{C}=\mathrm{O}$ stretching $)$ and $1620 \mathrm{~cm}^{-1}(\mathrm{C}=\mathrm{C}$ stretching $)$ presented greater intensities. Phenolic -OH groups $\left(3400 \mathrm{~cm}^{-1}\right.$, IR shoulder) were also well represented in these latter horizons. The abundance of oxygen may be related to the amount of both carboxyl groups, which are responsible for the large acidity of these compounds (see Caner, 2000), and hydroxyl-alcoholic groups, which probably derive from polysaccharides.

\subsection{2. $U V$-Visible spectroscopy}

The values of the selected optical parameters listed in Table 4, which show that the humification degree reaches its highest level (A-type) in HAs from the $A_{2}, A_{3}$ and $A_{4}$ horizons of the Nilg 4 and Nilg 16 pedons and from the $A_{3}$ and $A_{4}$ horizons of the Nilg 19 and Kota 0 pedons, are in agreement with the observed dark colour of these horizons (see Table 1). On the other hand, HAs from the $A_{1}$ horizons of the Nilg 4 and Nilg 16 pedons and

$\mathrm{A}_{1}$ and $\mathrm{A}_{2}$ horizons of the Nilg 19 and Kota 0 pedons presented a lower humification degree (B-type), again in agreement with their brown colours 
Table 4 Elemental organic composition, optical parameters and classification of the humic acids.

\begin{tabular}{|c|c|c|c|c|c|c|c|c|c|c|c|c|c|}
\hline Pedons & Horizon & Depth & Ash & $\mathrm{C}$ & $\mathrm{N}$ & $\mathrm{H}$ & $\mathrm{O}$ & $\mathrm{C} / \mathrm{N}$ & & $\mathrm{O} / \mathrm{C}$ & $\Delta \log K$ & $\overline{\mathrm{A}_{600} / \mathrm{C}}$ & $\mathrm{HA}^{\mathrm{b}}$ \\
\hline & /layer & $(\mathrm{cm})$ & & ------ & -)-(o & a =--- & ----- & $---(a$ & mic rat & --- & & & type \\
\hline Nilg 4 & & & & & & & & & & & & & \\
\hline & $\mathrm{A}_{11}$ & $0-10$ & 5.2 & 53.0 & 4.3 & 4.5 & 38.2 & 14.5 & 1.02 & 0.54 & 0.63 & 3.32 & $\mathrm{Rp}$ \\
\hline & $\mathrm{A}_{12}$ & $15-30$ & 3.1 & 53.7 & 3.6 & 5.7 & 36.9 & 17.2 & 1.27 & 0.52 & 0.58 & 5.86 & A \\
\hline & $A_{22}$ & $40-55$ & 7.5 & 56.8 & 2.6 & 2.8 & 37.8 & 25.2 & 0.58 & 0.50 & 0.57 & 6.83 & A \\
\hline Nilg 16 & & & & & & & & & & & & & \\
\hline & $\mathrm{A}_{11}$ & $0-10$ & 5.8 & 56.0 & 3.4 & 4.3 & 36.3 & 19.2 & 0.92 & 0.49 & 0.58 & 5.17 & B \\
\hline & $A_{21}$ & $20-35$ & 1.9 & 58.5 & 3.4 & 3.4 & 34.7 & 20.4 & 0.70 & 0.44 & 0.54 & 6.06 & $\mathrm{~A}$ \\
\hline & $A_{31}$ & $45-50$ & 8.6 & 56.1 & 2.2 & 2.7 & 39.0 & 29.9 & 0.58 & 0.52 & 0.54 & 6.77 & A \\
\hline & $\mathrm{A}_{4}$ & $60-70$ & 7.3 & 56.9 & 1.9 & 2.5 & 38.7 & 34.5 & 0.52 & 0.51 & 0.55 & 7.76 & A \\
\hline Nilg 19 & & & & & & & & & & & & & \\
\hline & $\mathrm{A}_{11}$ & $0-10$ & 0.3 & 53.9 & 4.9 & 4.9 & 36.3 & 12.9 & 1.09 & 0.51 & 0.73 & 2.65 & $\mathrm{P} / \mathrm{B}$ \\
\hline & $A_{21}$ & $15-25$ & 4.6 & 53.9 & 5.1 & 4.6 & 36.4 & 12.2 & 1.03 & 0.51 & 0.65 & 3.56 & B \\
\hline & $\mathrm{A}_{22}$ & $25-40$ & 9.8 & 52.5 & 4.5 & 4.2 & 38.9 & 13.8 & 0.96 & 0.56 & 0.61 & 3.29 & A \\
\hline & $\mathrm{A}_{32}$ & $60-70$ & 5.9 & 57.3 & 1.8 & 2.4 & 38.5 & 37.1 & 0.50 & 0.50 & 0.59 & 8.81 & $\mathrm{~A}$ \\
\hline Kota 0 & & & & & & & & & & & & & \\
\hline & $\mathrm{A}_{1}$ & $0-20$ & 2.7 & 53.7 & 4.2 & 4.6 & 37.6 & 15.1 & 1.02 & 0.53 & 0.69 & 3.42 & B \\
\hline & $\mathrm{A}_{22}$ & $30-40$ & 4.7 & 54.9 & 2.3 & 2.7 & 40.0 & 27.7 & 0.59 & 0.55 & 0.56 & 7.96 & $\mathrm{~A}$ \\
\hline & $A_{31}$ & $50-65$ & 3.9 & 55.9 & 2.0 & 2.7 & 39.3 & 32.0 & 0.58 & 0.53 & 0.56 & 7.81 & $\mathrm{~A}$ \\
\hline & $\mathrm{A}_{33}$ & $80-90$ & 3.4 & 58.9 & 1.6 & 2.4 & 37.0 & 42.9 & 0.50 & 0.47 & 0.59 & 7.03 & A \\
\hline & $\mathrm{A}_{42}$ & $\begin{array}{l}100- \\
120 \\
\end{array}$ & 3.7 & 57.6 & 1.5 & 2.1 & 38.8 & 46.1 & 0.44 & 0.51 & 0.58 & 8.06 & $\mathrm{~A}$ \\
\hline
\end{tabular}

${ }^{\mathrm{a}}$ Results are expressed ash-free basis. ${ }^{\mathrm{b}} \mathrm{HA}$ classification following Kumada (1987).

\subsection{3. ${ }^{13}$ C-NMR spectroscopy}

Fig. 4 presents the ${ }^{13} \mathrm{C}-\mathrm{NMR}$ spectra of the HAs extracted from organic matter-rich horizons. Two HA groups can be distinguished:

- HAs from the $A_{1}$ horizons were marked by the abundance of alkyl C (0-30 ppm), O-alkyl C (55-57 ppm related to $\mathrm{CH}_{3}-\mathrm{O}$ - groups derived from lignin), $\mathrm{N}$-alkyl groups and an intense carbonyl C region (170 ppm).

- HAs from the $\mathrm{A}_{3}$ horizons of the Nilg 16 and Kota 0 pedons were dominated by aromatic $\mathrm{C}$ (130 ppm) and carbonyls (170 ppm), whereas alkyl C (0-30 ppm) bands were virtually absent. The results confirm those obtained from elemental analysis and IR spectroscopy: aromatic HAs occurred in depth whereas relatively aliphatic ones were present close to the surface. 

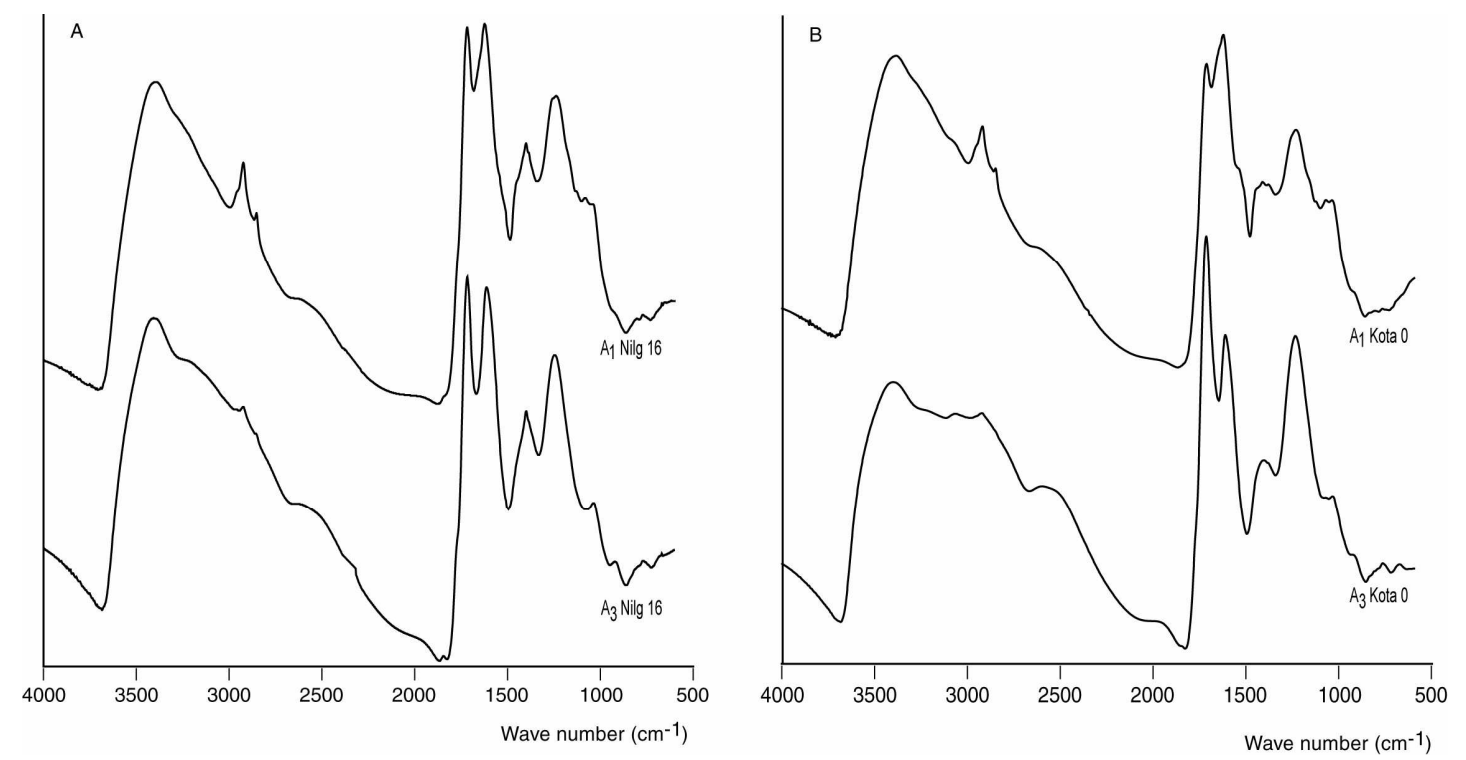

Figure 3: FT-IR spectra of humic acids from the Nilg 16 (A) and Kota 0 (B) pedons $\left(A_{1}\right.$ and $A_{3}$ horizons).

Moreover, the NMR spectra of the humic acids from the sombric-like subsurface A horizons of the Nilg 19 and Kota 0 pedons presented features that were very similar to those obtained by Golchin et al. (1997) on charred residues from grasses.

\section{Discussion}

\subsection{Vegetation changes recorded by the soils}

In the case of Nilgiris, as in many other tropical areas, C4-type plants generally dominate in grasslands whereas C3-type plants specifically occur in forests. Nevertheless, C3-type herbs may have also replaced C4-type grasses in grassland, particularly during the deglaciation period $(18,000-10,000 \mathrm{yr} \mathrm{BP})$, when high moisture conditions were supposed to have favoured C3-type species (Sukumar et al., 1993). In the present study, the interpretation of $\delta^{13} \mathrm{C}$ values in terms of plant formations does not pose any problem with regard to the $\mathrm{C} 4$ type plant signatures; it is clearly attributed to grassland formations. For the C3-type plant signatures, when a surface horizon is concerned, the nature of the current vegetation, forest or plantation is in agreement with this signature.

Taking the above interpretations into account, the data listed in Table 3 indicate that the four soils have recorded rather different vegetation successions. For instance, in Nilg 16, a clear grassland signature shows itself in a layer that is both close to the soil surface $(20-35 \mathrm{~cm})$ and characterized by a recent MRT ( 826 years BP). In contrast, the first $40 \mathrm{~cm}$ of the Nilg 19 epipedon have a SOM clearly deriving from a forest vegetation that already existed at this 

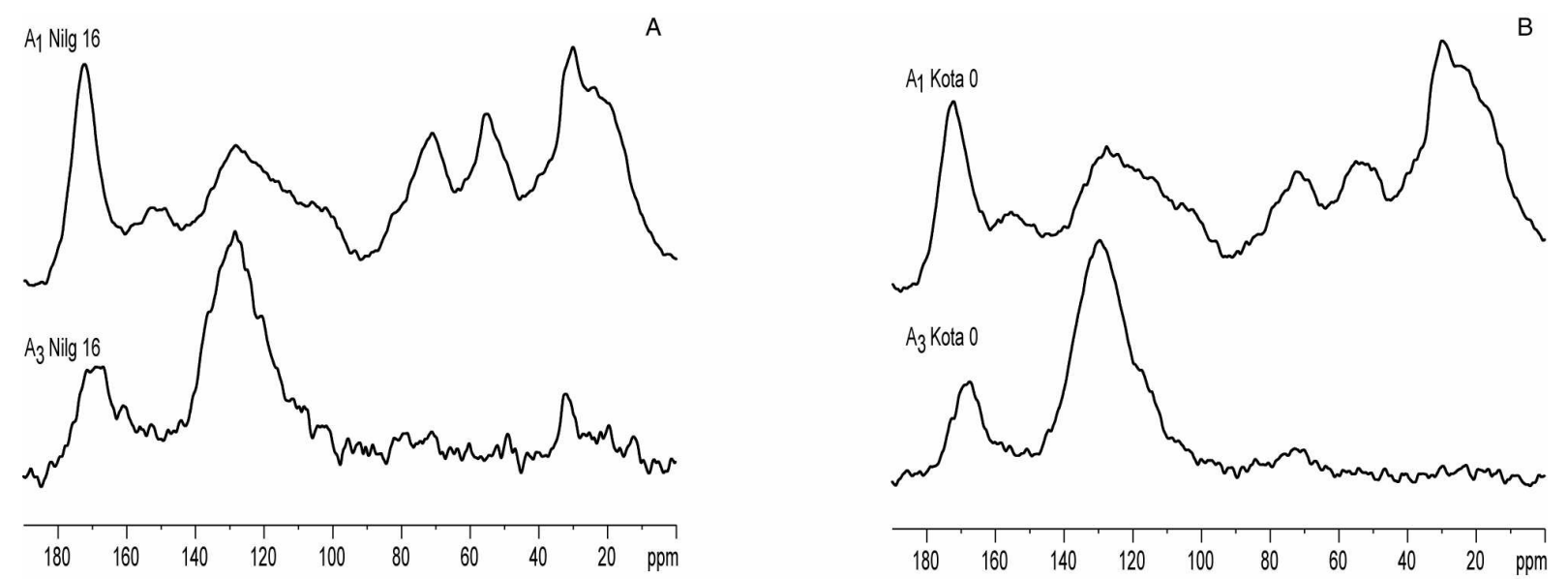

Figure 4: Solid state ${ }^{13} \mathrm{C}$-NMR spectra of humic acids from the Nilg 16 (A) and Kota 0 (B) pedons ( $\mathrm{A}_{1}$ and $\mathrm{A}_{3}$ horizons).

particular site 2,000 years ago. Thus, our results are obviously too limited and also too scattered to attempt any reconstitution of the recent history of the vegetation dynamic in the grassland-forest mosaic of the Nilgiris. They are, however, in reasonable agreement with the finding that the savanna extended considerably at the end of the Pleistocene (Sukumar et al., 1993; Rajagopalan et al., 1997). Similarly, they point to the fact that, where the sombric-like subsurface A horizons are present (as in the Nilg 19 and Kota 0 pedons), the change from grassland to forest vegetation took place earlier than at the sites where similar subsurface horizons were not observed.

\subsection{Organic matter origin, properties of humic acids and soil colour.}

Figure 5 presents graphs on which the $\delta^{13} \mathrm{C}$ of organic matter have been plotted against either the colour intensity values or the $\mathrm{H} / \mathrm{C}$ ratios of humic acids. Both graphs (Fig. 5A and 5B) reveal a similar trend: as the $\delta^{13} \mathrm{C}$ values increase, the chromatic and the chemical properties of humic acids are modified. Thus, the darkest and most condensed HAs (i.e. those belonging to the A-type category, see Table 4) show a clear tendency to have formed at the expense of a grassland vegetation.

Since the humic acids, along with the iron oxides, are the major pigments responsible for soil colour (Schulze et al., 1993), the data plotted in Fig. 5 can now be compared with the colours of the different A horizons listed in Table 1. We can then deduce (Fig. 5) that the horizons with Munsell chromas and values lower than $3 / 2$ belong to a population that includes the samples that have both a SOM derived most obviously from grassland and A-type humic acids. 

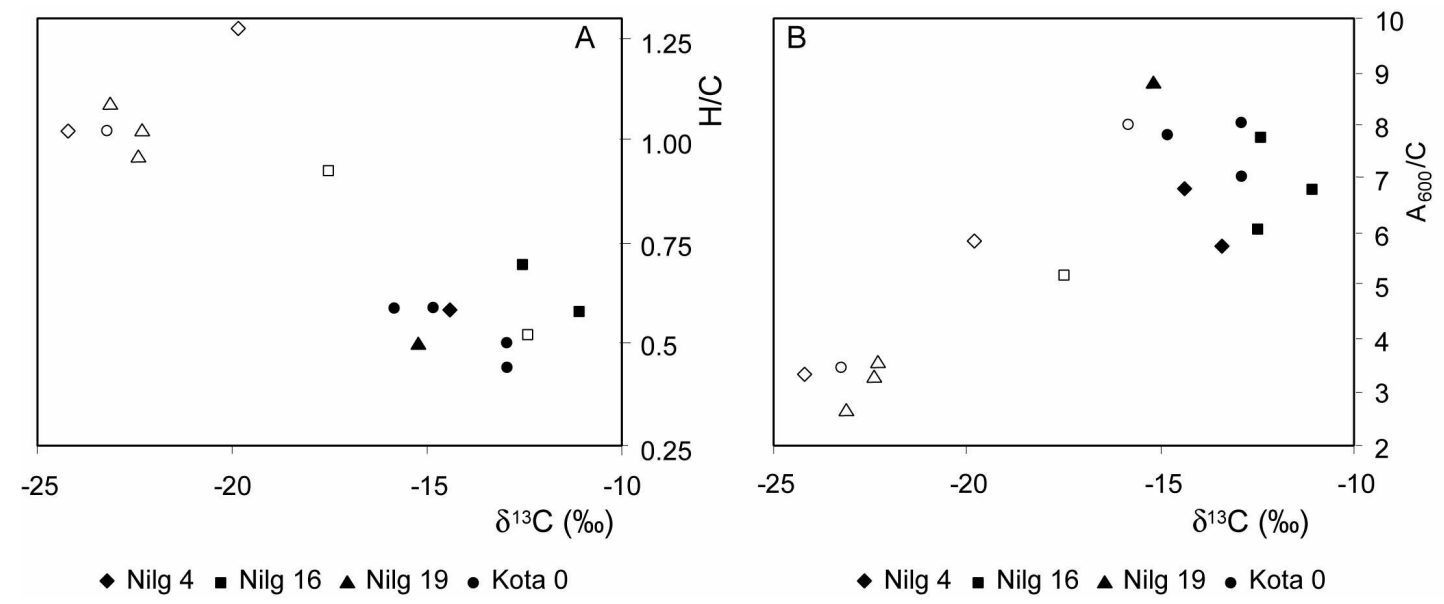

Figure 5: Plots of $\mathrm{H} / \mathrm{C}$ ratios (A) and colour intensity values (B) of HAs versus the SOM $\delta^{13} \mathrm{C}$ values. Samples having $\delta^{13} \mathrm{C}$ values higher than $-15 \%$ and aromatic and melanic HAs are part of a population that is statistically different from the one that includes the other samples. Filled symbols correspond to SOM from subsurface horizons having a Munsell colour of 5 YR 2.5/2., whereas open symbols correspond to SOM from horizons having a Munsell colour lighter than 5YR 2.5/2.

In other words, regardless of the origin and position of the samples in their respective epipedon, the darkest ones (those having a Munsell colour of 5YR 2.5/2) all contain A-type humic acids and organic matter derived from a grassland vegetation.

Despite the fact that the three Andisols of this are classified as Fulvudands, the relationships between soil colours and organic matter origin described above are consistent with previous observations concerning the differences existing between the dark Melanudands and the lighter coloured Fulvudands occurring in Japan (Shoji, 1988; Nanzyo et al., 1993). The former have also been reported to contain A-type humic acids inherited from grass vegetation whereas the latter occur most commonly under deciduous trees. Moreover, it has been shown (Golchin et al., 1997; Higashi et al., 1999) that where a grass ecosystem gives way to a deciduous forest, the Melanudands may loose their dark colour (and their characteristic Atype humic acids) after a very short period of time (i.e. a century or even less).

\subsection{Genesis of sombric-like subsurface horizons}

The pedons of this study present similarities and differences with the Andisols of Japan that loose their dark colour after a vegetation change. They also occur in sites that have experienced a vegetation change relatively recently (here, from a grassland-type vegetation towards a C3-type one) and a colour lightening is similarly observed but only in their upper A 
horizons. Moreover, in the Nilgiris, colour contrasts with depth remain noticeable in the same epipedon and this sometimes occurs to such an extent that two of the soils of this study can be identified as having sombric-like subsurface A horizons.

In view of these observations, we therefore suggest that the genesis of sombric-like subsurface horizons of the Nilgiris' soils results from the following sequence of events: (i) an exceptionally thick accumulation of dark organic matter deriving from grassland followed by (ii) its progressive replacement by less dark organic matter deriving from a C3-type vegetation during a sufficient time span and on a sufficient thickness of their upper A horizons. To be plausible, our proposal must also explain why the invasion of the Nilg 19 and Kota 0 pedons by organic matter deriving from a C3-type vegetation has left dark horizons in the deeper layers whose organic matter derives from a grassland vegetation. In this respect, two complementary factors are likely to have played a role. Firstly, the sombric-like horizons contain very large amounts of Al-humus complexes (up to $150 \mathrm{~g} \mathrm{~kg}^{-1}$, see Table 2) and these constituents are known to be particularly resistant to mineralisation (Boudot et al., 1988). Secondly, the fires that Blasco (1971) considers as the key factor in the stabilization of the grassland-forest mosaic of the Nilgiris may also have played a role. Indeed, the sombric-like horizons characteristically contain type-A humic acids, i.e. humic constituents that have been frequently considered as indicators of charred organic matter (Shindo et al., 1986; Skjemstad et al., 1996; Golchin et al., 1997) and, for this reason, considered as forming part of the most inert pool of SOM (Skjemstad et al., 1996).

\subsection{Sombric-like horizons of the Nilgiris versus the African sombric horizons}

So far, we have shown that one of the hypotheses proposed to account for the presence of sombric horizons in central Africa is consistent with the observations reported in the present study. In the Nilgiris, the dark subsurface horizons are the remnants of humification processes that have taken place under a former grassland vegetation. In Africa, the sombric horizons have many different facies (Frankart, 1983) and, as Van Wambeke (1992) observes, they occur in environments where their origin may be related to many different types of events. As far as we know, no analytical data similar to those discussed in this paper are available. Thus, we are certainly not in a position to extend our hypothesis to cover the whole African area where sombric horizons were reported to occur. However, we may underline coincidences. Beside similarities in terms of elevation and nature of the soil parent materials, there are now reports (e.g. Bonnefille et al., 1990) indicating that in Burundi, especially, the end of the Pleistocene was also characterized by an important extension of the savanna at elevations that 
were more recently colonized by the montane forest. On the other hand, in an early paper by Ruhe (1956), a climatic and associated vegetation change was already suggested to be at the origin of the development of sombric horizons. Finally, there is another puzzling similarity. As is clearly the case in the Nilgiris and in Central Africa as well, the dark subsurface horizons frequently have chemical and physical properties similar to those that are presently recognized as soil andic properties (Neel, 1983; Buol and Eswaran, 1987; Mutwewingabo, 1989).

\section{Conclusion}

The soils of the Nilgiris showing the clearest colour contrast between their dark subsurface horizons and their brown top A horizons have recorded the vegetation changes that they experienced since the end of the Pleistocene in their organic matter. SOM of the dark subsurface horizons derives from the grassland vegetation that existed more than 10,000 years ago, whereas top soil $\mathrm{OM}$ have the $\delta^{13} \mathrm{C}$ signature of organic constituents deriving from the C3-type vegetation that replaced the grassland more recently. On the other hand, the different horizon colours observed, as well as the different origins of their organic matter, are also reflected in the chromatic and chemical properties of their humic acids. In depth, the humic acids belong to the A-type category of Kumada (1987) whereas, in the top A horizons, similar highly aromatic and dark humic acids are absent.

In view of these results, the sombric-like subsurface A horizons observed in the Nilgiris are therefore considered to be the relics of humification processes that took place under a grassland vegetation in sites that, later experienced a surface lightening of their dark humus under the influence of a C3-type vegetation.

In the present paper, this interpretation, which is very similar to the hypothesis proposed by Van Wambeke (1992) to explain the genesis of some African sombric horizons, results from the utilization of approaches that were generally not available when the sombric horizon was initially defined. Since organic matter origin can now be more easily traced, these approaches should also to be used to see if the African sombric horizons would have inherited their dark SOM from a previous savanna vegetation as well.

\section{Acknowledgements}

The work on Nilgiri Andisols was completed within the framework of a $\mathrm{PhD}$ project cofunded by the French Institute of Pondicherry (India) and the Centre de Pédologie Biologique (CPB) of Nancy (France). The authors gratefully acknowledge P. Tekely (University of 
Nancy) for performing ${ }^{13} \mathrm{C}-\mathrm{NMR}$ spectroscopy of the humic acids and C. France-Lanord (CRPG, Nancy) for $\delta^{13} \mathrm{C}$ determinations. We also thank P.F. Van Bergen and F. Andreux for their helpful comments on an early version of this paper.

\section{References}

AGCD (Administration Générale pour la Coopération au Développement, Belgique, Publisher) 1987. Débat sur l'horizon sombre. In: Actes du dixième Forum International sur La Soil Taxonomy et les Transferts d'Agrotechnologie, pp 115-119.

Andreux, F., 1978. Etude de la stabilisation physico-chimique et biologique d'acides humiques modèles $\mathrm{Ph} . \mathrm{D}$. Thesis, University of Nancy, France.

Arai, S., Hatta, T., Tanaka, U., Hayamizu, K., Kigoshi, K., Ito O., 1996. Characterisation of the organic components of an Alfisol and a Vertisol in adjacent locations in Indian semi-arid tropics using optical spectroscopy, ${ }^{13} \mathrm{C}$-NMR spectroscopy, and ${ }^{14} \mathrm{C}$ dating. Geoderma, 69: 59-70.

Baert, G., Imerzoukène, P., Jamagne, S., Ndayiradjije, S., Pineros Garcia, J.D., 2000. Carte des sols du Rwanda au 1:50,000. Laboratoire de Pédologie. Université de Gand, Belgique

Balesdent, J., 1987. The turnover of soil organic fractions estimated by radiocarbon dating. The Science of Total Environment, 62: 405-408.

Balesdent, J., Guillet, B., 1982. Les datations par $1{ }^{14} \mathrm{C}$ des matières organiques des sols. Contribution à l'étude de l'humification et du renouvellement des substances humiques. Science du Sol, 2: 93111.

Blasco F., 1971. Montagnes du Sud de l'Inde: forêts, savanes, écologie. Travaux de la Section Scientifique et Technique $\mathrm{N}^{\circ} 10$, Institut Français de Pondichéry, Pondicherry, India.

Bonnefile, R., Roeland, J.C., Guiot, J., 1990. Temperature and rainfall estimates for the past 40,000 years in equatorial Africa. Nature, 346: 347-349.

Boudot, J.-P., Bel Hadj, B.A., Chone, T., 1988. Dependence of carbon and nitrogen mineralization rates upon amorphous metallic constituents and allophanes in Highland soils. Geoderma, 42: 245-260.

Boutton, T.W., 1996. Stable carbon isotope ratios of soil organic matter turnover and their use as indicators of vegetation and climate change. In: Boutton, T.W., Yamasaki, S. (Eds.) Mass spectrometry of soils. Marcel Decker Inc., New York, pp 47-82.

Buol, S.W., Eswaran, H., 1987. International Committee on Oxisols: Final report. technical Monograph No 17. Soil Management Support Services and North Carolina State University, Washington D.C. and Raleigh, N.C.

Caner L., 2000. Les sols humifères des "Hautes Terres" du massif des Nilgiri en Inde du Sud. Formation d'Andosols sur une ancienne couverture ferrallitique en relation avec les évolutions climatiques des derniers millénaires. Ph.D. Thesis, University of Nancy, France. 
Caner L., Bourgeon G., Toutain F., Herbillon A.J., 2000. Characteristics of non-allophanic Andisols derived from low activity clay regoliths in Nilgiri Hills (Southern India). European Journal of Soil Science, 51: 353-363.

Daly, B.K., 1982. Identification of podzols and podzolized soils in New Zealand by relative absorbance of oxalate extracts of A and B horizons. Geoderma, 28: 29-38.

Demangeot, J., 1975. Recherches géomorphologiques en Inde du Sud. Zeitschrift für Geomorphologie, 19: 229-272.

Desjardins, T., Carneiro Filho, A., Mariotti, A., Chauvel, A., Girardin, C., 1996. Changes of the ForestSavanna boundary in the Brazilian Amazonia during the Holocene revealed by stable isotope ratios of soil organic carbon. Oecologia, 108:749-756.

Eswaran, H., Tavernier, R., 1980. Classification and genesis of Oxisols. In: Theng, B.K.G. (Eds.) Soils with Variable Charge. New Zealand Society of Soil Science, Lower Hutt, pp. 427-442.

Frankart, R., 1983. The soils with sombric horizons in Rwanda and Burundi. In: Beinroth, F.H., Neel, H., Eswaran, H. (Eds.), Proceedings of the Fourth International Soil Classification Workshop, Rwanda 2-12 June 1981 - Part I: Papers. ABOS-AGCD, Brussels, pp. 48-64.

Gavinelli, E., Feller, C., Larré-Larrouy, M.C., Bacye, B., Djegui, N., Nzila, J., 1995. A routine method to study soil organic matter by particle-size fractionation: examples for tropical soils. Communications in Soil Science and Plant Analysis, 26: 1749-1760.

Golchin, A., Baldock, J.A., Clarke, P., Higashi, T., Skjemstad, J.O., Oades, J.M., 1997. The effects of vegetation and burning on the chemical composition of soil organic matter in volcanic ash soil as shown by ${ }^{13} \mathrm{C}$ NMR spectroscopy. I. Whole soil and humic acid fraction. Geoderma, 76: 155-174.

Guillet, B., Faivre, P., Mariotti, A., Khobzi, J., 1988. The ${ }^{14} \mathrm{C}$ dates and ${ }^{13} \mathrm{C} /{ }^{12} \mathrm{C}$ ratios of soil organic matter as a mean of studying the past vegetation in intertropical regions: example from Colombia (South America). Palaeogeography, Palaeoclimatology, Palaeoecology, 65: 51-58.

Gunnell, Y., Louchet, A., 2000. The influence of rock hardness and divergent weathering on the interpretation of apatite fission track denudation rates. Evidence from charnockites in South India and Sri Lanka. Zeitschrift für Geomorphologie, 44: 33-57.

Gupta, H.P., Prasad, K., 1985. The vegetational development during 30,00 years B.P. at Colgrain, Ootcamund, Nilgiris, South India. Journal of Palynology, 21: 174-187.

Higashi, T., Sakamoto, T., Tamura, K., 1999. Changes in some properties of humic substances from Melanudands induced by vegetational succession from grass to deciduous trees. In: Berthelin, J., Huang, P.M., Bollag, J.M., Hardbound, F.A. (Eds.), Effect of Mineral-Organic-Microorganism Interactions on Soil and Freshwater Environments. Kluwer Academic/Plenum Publishers, New York, pp. 203-211. 
Honna, T., Yamamoto, S., Matsui, K., 1988. A simple procedure to determine melanic index that is useful for differentiating melanic from fulvic Andisols. Pedologist, 32: 69-78.

Kögel-Knabner, I., 1997. ${ }^{13} \mathrm{C}$ and ${ }^{15} \mathrm{~N}$ NMR spectroscopy as a tool in soil organic matter studies. Geoderma, 80: 243-270.

Kumada, K., 1987. Chemistry of soil organic matter. Developments in Soil Science, Elsevier, Tokyo.

Mariotti, A., Peterschmitt, E., 1994. Forest savanna ecotone dynamics in India as revealed by carbon isotope ratios of soil organic matter. Oecologia, 97: 475-480.

Mutwewingabo, B., 1989. Genèse, caractéristiques et contraintes des sols acides à horizon sombre de profondeur de la région de haute altitude du Rwanda. In: Soiltrop 89, Editions ORSTOM, collection Colloques et Séminaires, Paris, pp. 353-385.

Nanzyo, M., Dahlgren, R., Shoji, S. 1993. Chemical characteristics of volcanic ash soils. In: Shoji, S., Nanzyo, M., Dahlgren R.A. (Eds.), Volcanic Ash Soils - Genesis, Properties and Utilization, Developments in Soil Science, 21, Elsevier, pp. 145-187.

Neel, H., 1983. An overview of the physiography and the soils of Rwanda. In: Beinroth, F.H., Neel, H., Eswaran, H. (Eds.), Proceedings of the Fourth International Soil Classification Workshop, Rwanda 2-12 June 1981 - Part II: Field Trip and Background Soil Data. ABOS-AGCD Brussels.

Poulenard, J., Herbillon, A.J., 2000. Sur l'existence de trois catégories d'horizons de référence dans les andosols. C. R. Acad. Sci. Paris, série IIa 331: 651-657.

Preston, C.M., 1996. Application of NMR to soil organic matter analysis: History and prospects. Soil Science, 161: 144-166.

Rajagopalan, G., Sukumar, R., Ramesh, R., Pant, R.K., Rajagopalan, G., 1997. Late Quaternary vegetational and climatic changes from tropical peats in southern India - An extended record up to 40,000 years B.P. Current Science, 73: 60-63.

Ruhe, R.V., 1956. Landscape evolution in the High Ituri, Belgian Congo. Publication INEAC, Série Scientifique, 66, Bruxelles.

Schulze, G.D., Nagel, J.L., Van Scoyoc, J.E., Henderson, T.L., Baumgardner, M.F., Stott, D.E., 1993. Significance of organic matter in determining soil colors. In: Bigham, J.M., Ciolkosz, E.J. (Eds.), Soil Color. Soil Science Society of America, SSSA Special Publication, 31, Madison, pp. 71-90.

Sehgal, J.L., Natarajan, P., Reddy, P.S.A., Dhanapalan Mori A., 1996. Tamil Nadu Soils. 4 sheets at 1:500,000 scale. National Bureau of Soil Survey and Land Use Planning in co-operation with Department of Agriculture of Tamil Nadu, Bangalore, India.

Shindo, H., Higashi, T., Matsui, Y., 1986. Comparison of humic acid from charred residues of Susuki (Eulalia, Miscanthus sinensis A.) and from the A horizon of volcanic Ash soils. Soil Science and Plant Nutrition, 32: 579-586. 
Shoji, S., 1988. Separation of melanic and fulvic Andisols. Soil Science and Plant Nutrition, 34: 303306.

Skjemstad, J.O., Clarke, P., Taylor, J.A., Oades, J.M., McClure, S.G., 1996. The chemistry and nature of protected carbon in soils. Australian Journal of Soil Research, 34: 251-271.

Soil Survey Division Staff, 1993. Soil Survey Manual. Soil Conservation Service. U.S. Department of Agriculture Handbook No 18.

Soil Survey Staff, 1999. Soil Taxonomy. A basic system of classification for making and interpreting soil surveys, 2nd edition. Agriculture Handbook No 436.

Steelink C., 1985. Implication of elemental characteristics of humic substances. In: Aiken, G.R., McKnight, D.M., Wershaw, R.L., McCarthy, P. (Eds.), Humic Substances in Soil, Sediment, and Water. Geochemistry, isolation and characterization. Wiley Interscience, New York, pp. 457-476.

Stevenson, F.J., 1982. Humus Chemistry; Genesis, composition, Reactions. Wiley-Interscience, New York.

Subramanian, K. S., Murthy, M.V.N., 1976. Bauxite and hematite cappings in the Nilgiri - Study from geomorphologic angle. Journal of the Geological Society of India, 17: 353-358.

Subramanian, K S., Mani, G., 1981. Genetic and geomorphic aspects of laterites of high and low landforms in parts of Tamil Nadu, India. In: Proceedings of the International Seminar on Laterisation Processes. Trivandrum, India, Balkema, Rotterdam, pp. 237-245.

Sukumar, R., Ramesh, R., Pant, R.K., Rajagopalan, G., 1993. A $\delta^{13}$ C record of late quaternary climate change from tropical peats in southern India. Nature, 364: 703-706.

Sutra, J.-P., 1997. Histoire de la végétation et du climat au cours des 30 derniers millénaires dans le massif des Nilgiri (Inde du sud) : approche palynologique. Ph.D. Thesis, University Aix-Marseille III.

Sys, C., 1972. Caractérisation morphologique et physico-chimique de profils types de l'Afrique Centrale. Publications de l'Institut National pour l'Etude Agronomique du Congo (INEAC).

Sys, C., Van Wambeke, A., Frankart, R., Gilson, P., Jongen, P., Pécrot, A. Berce, J.M., Jamagne M., 1961. La cartographie des sols au Congo. Publication de l'Institut National pour l'Etude Agronomique du Congo (INEAC), Série Technique No 66, Bruxelles.

Van Wambeke, A., 1992. Soils of the tropics - Properties and appraisal. McGraw-Hill, New York.

Yonebayashi, K., Hattori, T., 1988. Chemical and biological studies on environmental humic acids. I. Composition of elemental and functional groups of humic acids. Soil Science and Plant Nutrition, 34: 571-584. 